\title{
Carbon and nitrogen flow, and trophic relationships, among the cultured species in an integrated multi-trophic aquaculture (IMTA) bay
}

\author{
Tariq Mahmood ${ }^{1,4, *}$, Jianguang Fang ${ }^{2}$, Zengjie Jiang ${ }^{2}$, Jing Zhang ${ }^{3}$ \\ ${ }^{1}$ School of Resources and Environmental Science, East China Normal University, 3663 North Zhongshan Road, \\ Shanghai 200062, PR China \\ ${ }^{2}$ Key Laboratory of Sustainable Utilization of Marine Fisheries Resources, Ministry of Agriculture, \\ Yellow Sea Fisheries Research Institute, Chinese Academy of Fishery Sciences, Qingdao 266071, PR China \\ ${ }^{3}$ State Key Laboratory of Estuarine and Coastal Research, East China Normal University, 3663 North Zhongshan Road, \\ Shanghai 200062, PR China \\ ${ }^{4}$ Present address: National Institute of Oceanography, St 47, Block 1, Clifton, Karachi 75600, Pakistan
}

\begin{abstract}
Stable isotopic signatures of organic carbon $\left(\delta^{13} \mathrm{C}\right)$ and total nitrogen $\left(\delta^{15} \mathrm{~N}\right)$ were measured on suspended particulates and sediments in order to understand the sources of organic matter (OM), water quality and flow of organic carbon and nitrogen among integrated multitrophic aquaculture (IMTA) species, as well as to evaluate the role of IMTA practice in accumulation and assimilation of OM during wet and dry seasons. OM distribution and composition were studied during 2011 in Sanggou Bay (SGB) of northern China, a system that receives terrestrial and oceanic inputs, and which is used for IMTA ventures. Results showed that higher terrestrial input of OM occurs during the wet compared to the dry season in the SGB. OM in suspended particulates (POM) showed marine- and terrestrial-derived signatures during the wet season, as revealed from their ranges in $\delta^{13} \mathrm{C}(-27.4$ to $-20.7 \%)$ and $\delta^{15} \mathrm{~N}(4.7$ to $9.4 \%)$. Sedimentary organic matter (SOM) showed signatures of marine-derived OM during both seasons, with ranges in $\delta^{13} \mathrm{C}$ and $\delta^{15} \mathrm{~N}$ of -22.4 to $-21.4 \%$ and 1.7 to $6.4 \%$, respectively. Shellfish and combined (shellfish, seaweed) cultures in SGB have the potential to reduce OM received from the fish cages as well as from the seasonal inputs from rivers. Mixing with Yellow Sea water, combined with prevailing circulation, favours the dispersal, dilution and transformation of OM and maintains and improves water quality. Based on our results, and compared with previous studies, the water quality of the SGB is likely to be sustained by IMTA activities.
\end{abstract}

KEY WORDS: IMTA $\cdot \mathrm{POM} \cdot \mathrm{SOM} \cdot \mathrm{Carbon}$ isotope $\cdot$ Nitrogen isotope $\cdot$ Trophic levels $\cdot$ Sanggou Bay

\section{INTRODUCTION}

Excess amounts of carbon and nitrogen produced either from land-based or offshore aquaculture activities are considered to be one of the main sources of pollution in coastal environments. Increasing coastal area development as well as aquaculture activities have been of particular concern to the health of coastal ecosystems. Land-based aquaculture waste is

${ }^{*}$ Corresponding author: tariqnio@gmail.com often discharged directly into shallow coastal areas, causing excessive organic and nutrient loads (Alabaster 1982). Offshore cage culture is considered to be a direct source of organic matter (OM) to the surrounding waters in the form of suspended detritus (Karakassis et al. 2000, Mazzola \& Sarà 2001), which mainly consists of uneaten feed and excretion products from the cultured fish (Holby \& Hall 1991, Hall et al. 1992). Furthermore, anthropogenic input provides

(C) The authors 2016. Open Access under Creative Commons by Attribution Licence. Use, distribution and reproduction are unrestricted. Authors and original publication must be credited. 
additional nutrient and OM enrichment in the coastal marine system (Evgenidou \& Valiela 2002). This waste affects not only the area in close proximity to the sources but can alter a wider coastal zone at various ecosystem levels; reducing the biomass, density and diversity of the benthos, plankton and nekton, and modifying natural food webs and stimulating eutrophication (Gowen et al. 1991, Pillay 1991, Vollenweider 1992, Duarte 1995). However, the offshore cultivation of shellfish together with seaweed could reduce the impact of OM waste and nutrients on the environment, as substantiated by land-based integrated aquaculture practice (Shpigel et al. 1991, Shpigel \& Neori 1996). The aquaculture-derived nutrients can be removed by seaweed biofilters (Buschmann et al. 2008). Such a combined species cultivation method, so-called integrated multi-trophic aquaculture (IMTA), is practiced in Chinese coastal zones. Besides the feasible ventures in mariculture schemes, the combination of trophic levels among cultured species in IMTA systems is also important in improving water quality. The IMTA of shellfish, seaweed and fish is common on the coast of northern China and has been in practice over 3 decades (Fang et al. 1996a,b, 2009).

Sanggou Bay (SGB) receives OM from both natural and anthropogenic sources, which subsequently impact the water quality of the bay. SGB is surrounded by a population of ca. 0.6 million in Rongcheng City of Shandong Peninsula. River runoff from Rongcheng City is considered the main source of nutrients into SGB and is composed on average of $65 \%$ crop land waste and $35 \%$ urban waste (Project SPEAR; Ferreira et al. 2007). Stable isotope analysis has been used successfully in determining sources of nutrition for consumers, evaluation of trophic relationship among organisms, understanding different sources of OM (terrestrial and marine) and environmental impact assessment (Wada et al. 1987, Risk \& Erdmann 2000, Costanzo et al. 2001). Stable isotope ratios of organic carbon $\left(\delta^{13} \mathrm{C}\right)$ and total nitrogen $\left(\delta^{15} \mathrm{~N}\right)$ have also been used to determine the impact of aquaculture waste on the environment (Ye et al. 1991, Vizzini \& Mazzola 2004, Yokoyama et al. 2006, Jiang et al. 2012). Aquaculture waste enters the food web and alters the natural isotopic composition of OM sources at both the base and upper trophic levels. Nitrogenrich fish waste mainly affects $\delta^{15} \mathrm{~N}$ values without or little alteration of $\delta^{13} \mathrm{C}$ (Vizzini \& Mazzola 2004). Aquaculture and human waste can affect at different levels of the ecosystem-reducing the biomass, density and diversity of the benthos, plankton and nekton-and modify natural food webs in coastal areas (Gowen et al. 1991, Pillay 1991).

In the present study, our first goal was to investigate the carbon and nitrogen flow from (1) phytoplankton, particulate OM (POM), sediment OM (SOM) or seaweed to filter feeders and (2) trash fish (feed provided to fish in fish cages) or plankton to omnivorous fish in an IMTA system in SGB using dual isotopic technique. A second objective was to study the isotopic profile $\left(\delta^{13} \mathrm{C}\right.$ and $\left.\delta^{15} \mathrm{~N}\right)$ of SOM and POM to understand the sources of carbon and nitrogen in SGB. Our study focused on understanding the role of lower trophic levels in the reduction of OM and clarifying whether aquaculture- and land-derived OM impact the water quality of the bay.

\section{MATERIALS AND METHODS}

\section{Study area}

The SGB $\left(37^{\circ} 01^{\prime}\right.$ to $37^{\circ} 09^{\prime} \mathrm{N}$ and $122^{\circ} 24^{\prime}$ to $\left.122^{\circ} 35^{\prime} \mathrm{E}\right)$ is located in Rongcheng Town, in Weihai City, on the Shandong Peninsula in northeastern China (Fig. 1). The bay is semi-enclosed and opens into the Yellow Sea (YS) in the east, covering an area of $144 \mathrm{~km}^{2}$. Freshwater inputs to the bay are mainly from one large river (the $\mathrm{Gu}$ River) and some small rivers ( $\mathrm{Ba}$, Sanggan, Yetao and Xiaolou Rivers). The bay experiences seasonal terrigenous inputs, with freshwater inflow being maximum in summer and with an average discharge of $1.7 \times 10^{8} \mathrm{~m}^{3}$ to $2.3 \times 10^{8} \mathrm{~m}^{3}$ (Rongcheng River Report 2012, www.rcsl.gov.cn). Water in the bay is well mixed and depth varies between 7.5 and $21 \mathrm{~m}$ (Zhao et al. 1996). IMTA is an important commercial activity in SGB. On the basis of culturing activities, the bay is divided into 4 culture areas. The southwest is used for shellfish and fish culture (hereafter, $\mathrm{SF}+\mathrm{F}$ ), the central part is dominated by polyculture of shellfish and seaweed $(\mathrm{SF}+\mathrm{SW})$, and the outer bay is cultivated with seaweed (SW) monoculture along the eastern boundary that opens into the YS (Fig. 1). Fish is cultured between May and October, while bivalve culture lasts between 1 and 2 yr. Red seaweed and kelp are cultivated from June-October and November-April, respectively (Zhao et al. 1996, SPEAR 2007). Shellfish and seaweed are cultivated in long lines around fish cages. Bivalve production includes the Chinese scallop Chlamys farreri $\left(\sim 60 \times 10^{3} \mathrm{t} \mathrm{yr}^{-1}\right)$ and the Pacific oyster Crassostrea gigas $\left(\sim 15 \times 10^{3} \mathrm{t} \mathrm{yr}^{-1}\right)$. Seaweed production includes kelp Saccharina japonica $(\sim 84 \times$

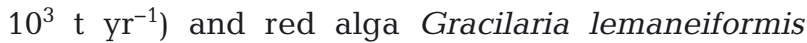




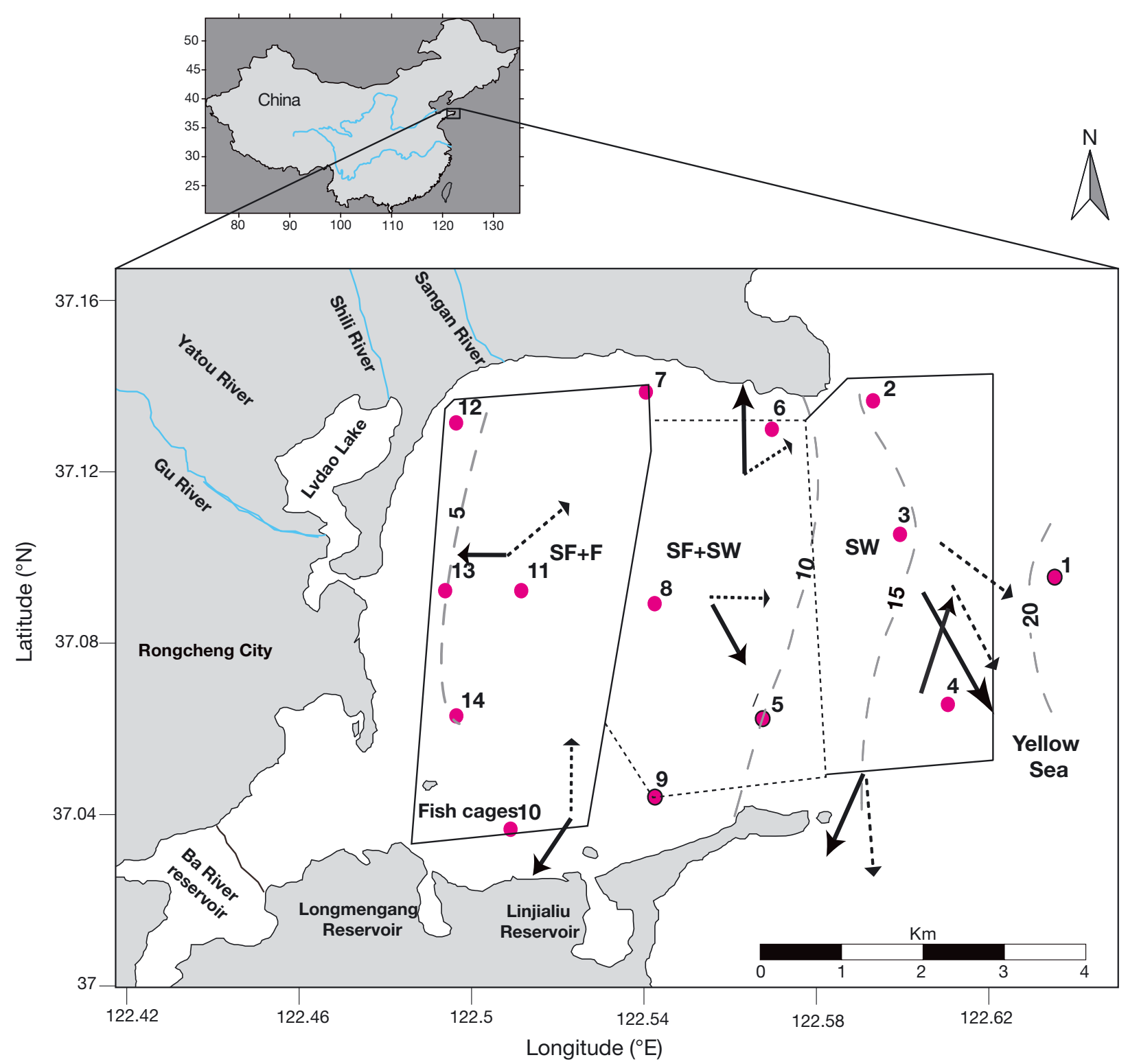

Fig. 1. Map of Sanggou Bay, showing culture areas (polygons with solid and dotted lines) and 14 stations (red dots) of cruises in August 2011 (wet season, summer) and January 2012 (dry season, winter). Culture areas include combined culture of shellfish and fish $(\mathrm{SF}+\mathrm{F})$, shellfish and seaweed $(\mathrm{SF}+\mathrm{SW})$ and monoculture of seaweed (SW). Solid arrows denote surface water current and dashed arrows bottom flow (source: Ferreira et al. 2007). Grey dashed lines denote isobaths (m)

$\left(\sim 25 \times 10^{3} \mathrm{t} \mathrm{yr}^{-1}\right)$. The production of Japanese flounder Paralichthys olivaceus is $\sim 24 \times 10^{3} \mathrm{t} \mathrm{yr}^{-1}$ (Rongcheng Fisheries Technology Extension Station 2012 statistics [www.rchy.gov.cn], summarized in Table 1).

\section{Sampling and analysis}

Samples for hydrographic parameters, POM, SOM, phytoplankton, zooplankton, shellfish (oyster and scallop), seaweed, cultured fish and trash fish were collected in August 2011 (wet season, i.e. summer) and January 2012 (dry season, i.e. winter). Surface water samples were collected using a Niskin water sampler at 14 stations covering all 3 culture areas in SGB (Fig. 1). The water samples were immediately screened through a $200 \mu \mathrm{m}$ mesh net to remove larger zooplankton and debris. They were filtered under vacuum onto prewashed, pre-combusted $\left(450^{\circ} \mathrm{C}\right.$, $4 \mathrm{~h}$ ) and pre-weighed Whatman GF/F filter papers ( $0.7 \mu \mathrm{m}$ pore size). The samples were subsequently stored at $-40^{\circ} \mathrm{C}$ in a freezer until laboratory analysis. 
Table 1. Summary of aquaculture in Sanggou Bay, where species are cultured in combination (SF+F, SF+SW) and monoculture (SW) in integrated multi-trophic aquaculture (IMTA). Additional details on the cultured area, annual production, and stocking, harvesting and culture periods for the different groups are also given (data from Zhao et al. 1996, Ferreira et al. 2007, Rongcheng Fisheries Technology Extension Station 2012 statistics [www.rchy.gov.cn])

\begin{tabular}{|c|c|c|c|c|c|}
\hline Cultured species & $\begin{array}{c}\text { Cultured area }\left(\mathrm{km}^{2}\right), \\
\text { total per group }\end{array}$ & $\begin{array}{l}\text { Stocking } \\
\text { period }\end{array}$ & $\begin{array}{l}\text { Harvesting } \\
\text { period }\end{array}$ & $\begin{array}{l}\text { Culture } \\
\text { period }\end{array}$ & $\begin{array}{l}\text { Production } \\
\left(\mathrm{t} \mathrm{yr}^{-1}\right)\end{array}$ \\
\hline \multicolumn{6}{|l|}{ Shellfish (SF) } \\
\hline Chlamys farreri (Chinese scallop) & 32 & May & March & $1-2 \mathrm{yr}$ & $\sim 60 \times 10^{3}$ \\
\hline Crassostrea gigas (Pacific oyster) & & May & March & $1-2 \mathrm{yr}$ & $\sim 15 \times 10^{3}$ \\
\hline \multicolumn{6}{|l|}{ Seaweed (SW) } \\
\hline Saccharina japonica (kelp) & 40 & November & April & $6 \mathrm{mo}$ & $\sim 84 \times 10^{3}$ \\
\hline Gracilaria lemaneiformis (Gracilaria) & & June & October & $5 \mathrm{mo}$ & $\sim 25 \times 10^{3}$ \\
\hline \multicolumn{6}{|l|}{ Fish (F) } \\
\hline Paralichthys olivaceus (Japanese flounder) & 0.36 & May & October & $6 \mathrm{mo}$ & $\sim 24 \times 10^{3}$ \\
\hline
\end{tabular}

Bottom sediment samples were collected with a Van Veen grab (Hydro-bios) from a few stations and then frozen at $-20^{\circ} \mathrm{C}$ until analysis. Salinity and chlorophyll a (chl a) were measured in situ with a multi-parameter instrument (Model: YSI Professional plus USA) and an ACLW-RS chlorophyll sensor, respectively. Cultured fish, shellfish, seaweed and trash fish samples were collected by local fishermen at some sampling sites. Phytoplankton $(60 \mu \mathrm{m})$ and zooplankton $(200 \mu \mathrm{m})$ nets were used to collect plankton samples. Plankton samples were filtered through Whatman GF/F filter papers, then frozen at $-40^{\circ} \mathrm{C}$ until analysis. All samples of fish, shellfish and trash fish were rinsed carefully with filtered seawater and guts were removed to reduce bias. Muscle of cultured fish, trash fish and shellfish, as well as sediments and particulate samples, were dried at $60^{\circ} \mathrm{C}$ for at least $24 \mathrm{~h}$ prior to stable isotope analysis. Cultured fish, trash fish and bivalve samples were soaked in $1.2 \mathrm{~N} \mathrm{HCl}$ for $30 \mathrm{~min}$, rinsed with distilled water, dried at $60^{\circ} \mathrm{C}$ and ground to a powder. The bottom sediment samples were ground and sieved through a $0.2 \mu \mathrm{m}$ mesh, and then both the sediments and particulate samples were digested with $1 \mathrm{M} \mathrm{HCl}$ to remove carbonates and dried at $60^{\circ} \mathrm{C}$ for $12 \mathrm{~h}$. Samples for total nitrogen concentration and isotopes were directly measured without the acid treatment (Cui et al. 2012).

Organic carbon, total nitrogen content and isotopes of carbon and nitrogen were measured using a Finnigan EA-1112 elemental analyzer interfaced with a Finnigan Delta plus XP continuous flow isotope ratio mass spectrometer. Carbon and nitrogen isotope ratios are expressed in the delta notation $\delta^{13} \mathrm{C}$ and $\delta^{15} \mathrm{~N}$ relative to Vienna Pee Dee Belemnite and atmospheric nitrogen, respectively, and expressed as (Hayes 2004):

$$
\delta X=\left[\left(R_{\text {sample }} / R_{\text {standard }}\right)-1\right] \times 1000(\% \text { o })
$$

where, $X={ }^{13} \mathrm{C}$ or ${ }^{15} \mathrm{~N}$, and $R={ }^{13} \mathrm{C}:{ }^{12} \mathrm{C}$ for $\delta^{13} \mathrm{C}$ or ${ }^{15} \mathrm{~N}:{ }^{14} \mathrm{~N}$ for $\delta^{15} \mathrm{~N}$.

Internal standards of caffeine and cellulose were used for calibration during the measurements. The average precision for organic carbon and total nitrogen measurements during this study was $\pm 0.1 \%$.

Trophic levels among the cultured species were calculated using the following formula (Wan et al. 2010):

$$
\begin{aligned}
& \text { Trophic level }= \\
& {\left[\left(\text { consumer } \delta^{15} \mathrm{~N}-\text { phyto } \delta^{15} \mathrm{~N}\right) / 3.2\right]+1}
\end{aligned}
$$

where 3.2 represents the average enrichment of $\delta^{15} \mathrm{~N}$ among trophic levels in the present study, obtained by calculating the average value of $\delta^{15} \mathrm{~N}$ of each trophic level. This value is close to the enrichment factor of 3.1 reported by Wan et al. (2010) in a YS trophic level study.

\section{Statistical analysis}

SPSS 17.0 and Golden Software Grapher 9 were used to perform data analysis. Seasonal variation in $\delta^{13} \mathrm{C}$ and $\delta^{15} \mathrm{~N}$ of POM and SOM were examined using 1-way ANOVA. Difference of $\delta^{13} \mathrm{C}$ and $\delta^{15} \mathrm{~N}$ values of POM and SOM were analyzed by a paired t-test (Cui et al. 2012).

\section{RESULTS}

\section{Hydrographic parameters}

A negative correlation between salinity and chl $a$ was observed in the wet season $\left(r^{2}=-0.82 ; p<0.05\right)$. The coastal region was dominated by low salinity 

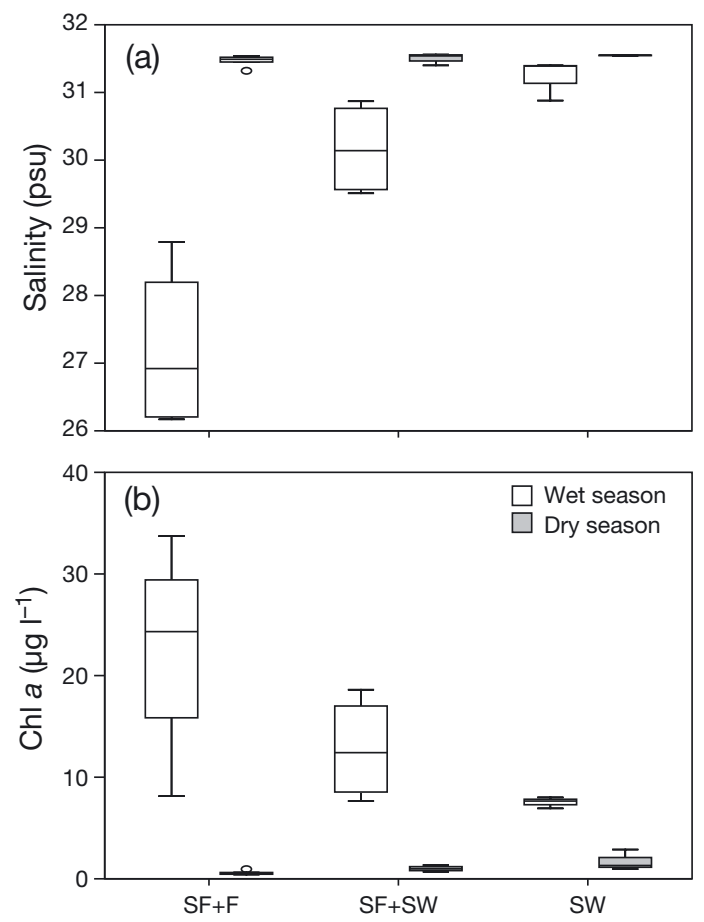

Fig. 2. Surface distribution of (a) salinity and (b) chlorophyll a in the 3 culture areas (see Fig. 1) in Sanggou Bay during the wet and dry seasons. Box plots show the median value (line), 25 and $75 \%$ quantiles (box), 5 and 95\% quantiles (whiskers), and outliers (circles)

and high chl a concentration. Slightly lower salinity and higher chl a concentrations were found in the $\mathrm{SF}+\mathrm{F}$ culture area of the bay compared to $\mathrm{SF}+\mathrm{SW}$ and SW culture areas. The other 2 culture areas showed high salinity and low chl a concentrations. The maximum salinity and minimum chl $a$ values were observed in the SW culture region (Fig. 2). The average values of salinity and chl a during the wet season in SGB were $29.4 \pm 2.0 \mathrm{psu}$ and $15.5 \pm 10.9 \mu \mathrm{g}$ $\mathrm{l}^{-1}$ (Fig. 2), respectively. There was no significant variation in salinity among the aquaculture areas during the dry season (Fig. 2), due to low freshwater input into the bay. Considering all culture areas of SGB in the dry season, salinity ranged between 31 and $32 \mathrm{psu}$, with an average $( \pm \mathrm{SD})$ of $31.5 \pm 0.07 \mathrm{psu}$. During the dry season, the average $( \pm \mathrm{SD}) \mathrm{chl} a$ concentration was $1.0 \pm 0.63 \mu \mathrm{g} \mathrm{l}^{-1}$. Chl a was significantly higher in the SW culture area in the offshore region than in the $\mathrm{SF}+\mathrm{F}$ area in the coastal region of the bay (Fig. 2).

\section{Stable isotope analysis of biological samples}

The weight percentages of organic carbon in cultured fish and shellfish were higher than in plankton and seaweed. The maximum values of nitrogen ( $\%$ dry wt) were found in cultured fish and minimum values in plankton (Fig. 3). The $\mathrm{C} / \mathrm{N}$ ratios of cultured fish, oysters, scallops and trash fish were in the range of $2.7-2.8,3.6-4.0,5.2-5.4$ and $4.4-4.5$, respectively, which were lower than the $\mathrm{C} / \mathrm{N}$ ratios of phytoplankton (9.9), zooplankton (11.6) and Gracilaria spp. (hereafter simply Gracilaria) (10.0). $\delta^{13} \mathrm{C}$ versus $\delta^{15} \mathrm{~N}$ values of SOM, POM, biological samples and the trophic level of the cultured species are shown in Fig. 4. The respective average values $( \pm \mathrm{SD})$ of $\delta^{13} \mathrm{C}$ and $\delta^{15} \mathrm{~N}$ were $-21.1 \pm 0.1 \%$ and $9.2 \pm 0.4 \%$ for scallops, $-21.1 \pm 0.2 \%$ and $11.2 \pm 0.3 \%$ o for oysters, $-20.9 \pm 0.1 \%$ and $6.7 \%$ for Gracilaria, $-19.0 \pm 0.2 \%$ and $-21.0 \pm 0.6 \%$ for cultured fish, and $11.1 \pm 0.3 \%$ and $9.6 \pm 1.2 \%$ for trash fish.

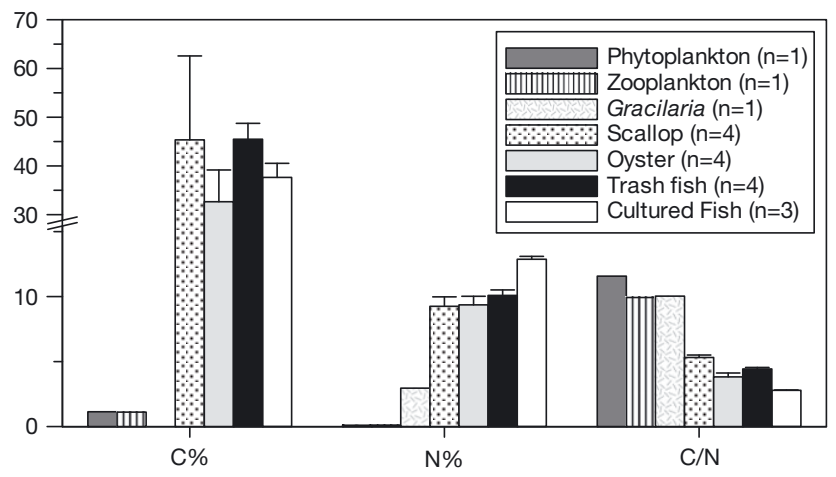

Fig. 3. Carbon and nitrogen contents (\% dry wt) and $\mathrm{C} / \mathrm{N}$ ratios of cultured species (seaweed, shellfish and fish; see Table 1) and of phyto- and zooplankton and input feed (i.e trash fish) in Sanggou Bay during the wet season. Means \pm SD

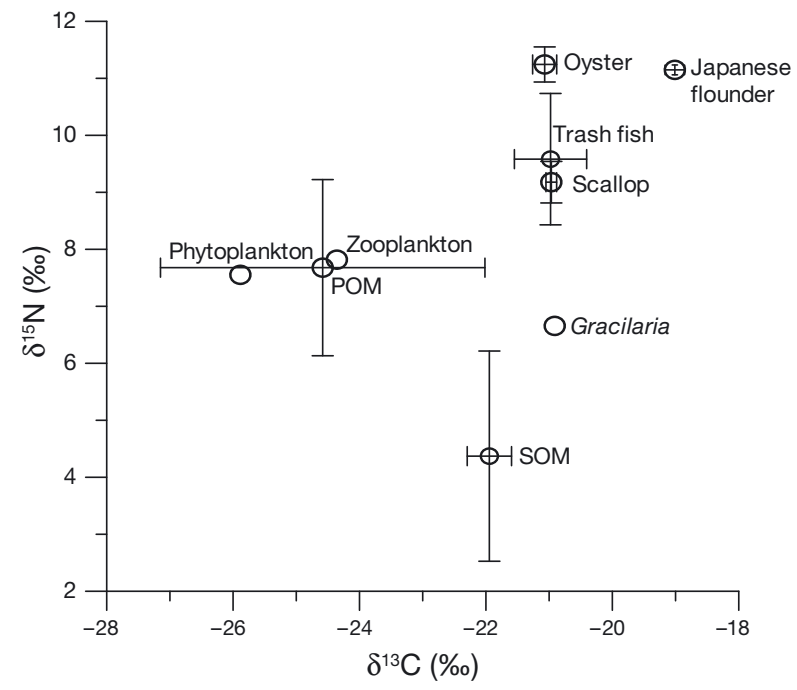

Fig. 4. $\delta^{15} \mathrm{~N} \%$ versus $\delta^{13} \mathrm{C}(\%)$ isotopic signatures of plankton, cultured species, trash fish, and particulate and sediment organic matter from Sanggou Bay during the wet season. Means given $\pm S D$, if $n>1$ 

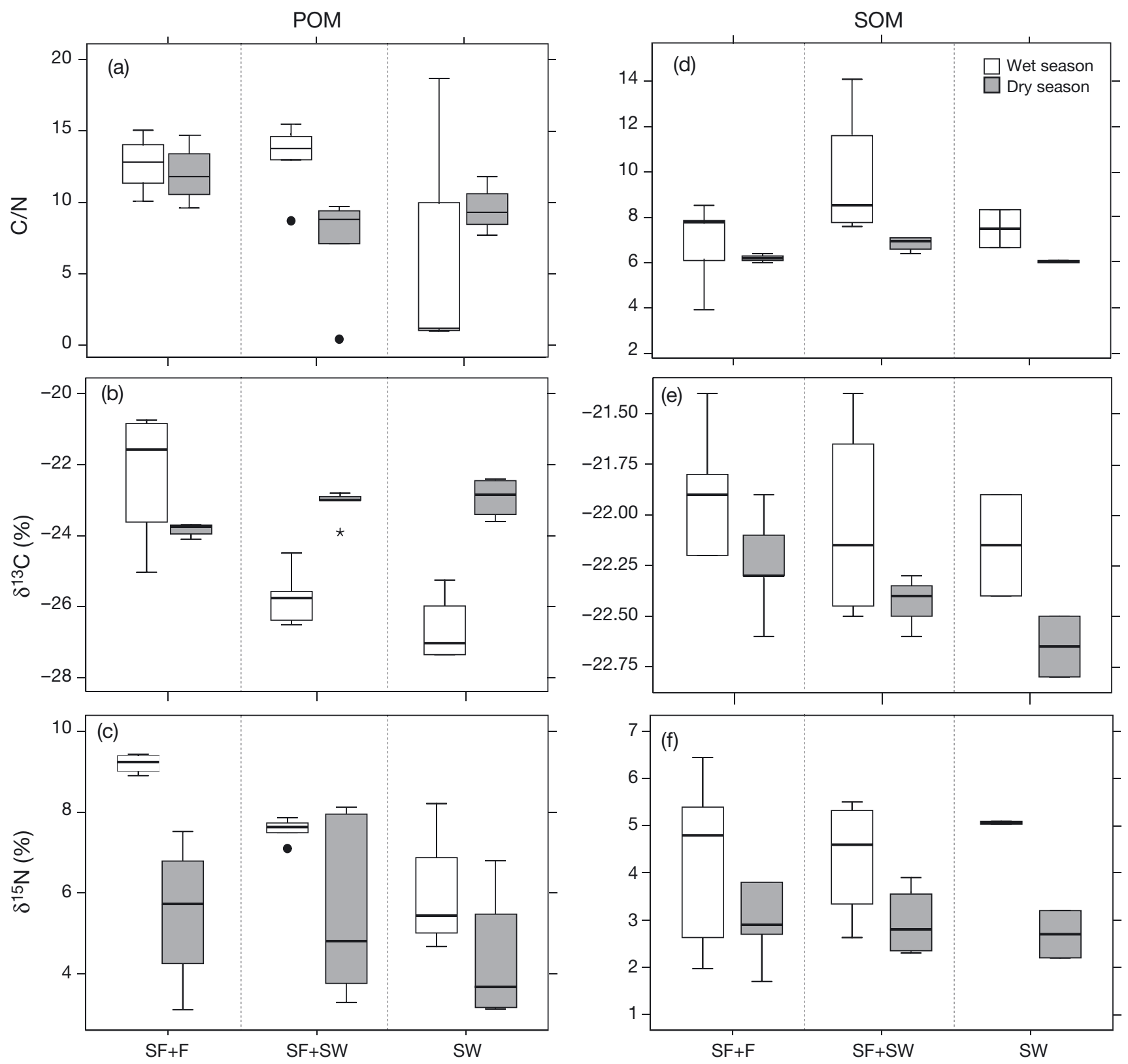

Fig. 5. Distribution of $\mathrm{C} / \mathrm{N}, \delta^{13} \mathrm{C}(\%)$ and $\delta^{15} \mathrm{~N}(\%)$ of $(\mathrm{a}-\mathrm{C})$ particulate (POM) and (d-f) sediment organic matter (SOM) in the 3 culture areas (see Fig. 1) of Sanggou Bay during the wet and dry seasons. Box plots show the median value (line), 25 and $75 \%$ quantiles (box), 5 and $95 \%$ quantiles (whiskers), outliers (black dots) and extremes (stars)

\section{Stable isotope analysis of SOM and POM in culture areas}

The distribution of $\mathrm{C} / \mathrm{N}, \delta^{13} \mathrm{C}$ and $\delta^{15} \mathrm{~N}$ of $\mathrm{SOM}(\mathrm{n}=$ 26) and POM $(\mathrm{n}=28)$ in the 3 culture areas of SGB during the wet and dry seasons is shown in Fig. 5. The fish cage culture and long-line culture of Gracilaria in SGB are performed during the wet season. Mixing of the bay water with the YS is higher in the SW culture area compared to the central $(\mathrm{SF}+\mathrm{SW})$ area. In the wet season, the lowest (1.16) and highest (18.68) C/N values of POM were observed in the SW culture area (Fig. 5a). For SOM, the lowest $\mathrm{C} / \mathrm{N}$ value (3.93) was found in the $\mathrm{SF}+\mathrm{F}$ culture area and the highest (14.09) in the SF+SW area (Fig. 5d). Highest values of $\delta^{13} \mathrm{C}$ and $\delta^{15} \mathrm{~N}$ of POM were found in the $\mathrm{SF}+\mathrm{F}$ culture area $(-20.74 \%$ and $9.43 \%$, respectively) and the lowest in the SW culture area $(-27.35 \%$ and $4.68 \%$, respectively) (Fig. $5 \mathrm{~b}, \mathrm{c}$ ). The $\delta^{15} \mathrm{~N}$ values of POM showed a decreasing trend from $\mathrm{SF}+\mathrm{F}$ to sea- 
ward (Fig. 5c). In contrast, no significant difference was found in the distribution of $\delta^{13} \mathrm{C}$ of SOM among the 3 culture areas in the wet season (Fig. $5 \mathrm{e}$ ). $\delta^{15} \mathrm{~N}$ values of SOM also showed no significant difference among the 3 culture areas in the wet season (Fig. 5f).

In the dry season, POM maximum and minimum $\mathrm{C} / \mathrm{N}$ ratios were observed in $\mathrm{SF}+\mathrm{F}$ (14.77) and $\mathrm{SF}+\mathrm{SW}$ (0.39) culture areas, respectively, whereas for SOM no significance difference was found in $\mathrm{C} / \mathrm{N}$ ratios among the 3 culture areas (Fig. $5 a, d$ ). The $\delta^{13} \mathrm{C}$ values of POM and SOM were in the range of $-24.06 \%$ to $-21.88 \%$, with only minor variations being observed between POM and SOM (Fig. 5b,e). The lowest value $\left(3.12 \%\right.$ o) of $\delta^{15} \mathrm{~N}$ of POM was found in the $\mathrm{SF}+\mathrm{F}$ culture area and the highest $(8.12 \%$ ) in $\mathrm{SF}+\mathrm{SW}$ (Fig. 5c). A slight, though non-significant, decrease in SOM $\delta^{15} \mathrm{~N}$ was observed from $\mathrm{SF}+\mathrm{F}$ to $\mathrm{SW}$ culture areas (Fig. 5f).

Within SGB overall, significant differences in $\delta^{13} \mathrm{C}$, $\delta^{15} \mathrm{~N}$ and $\mathrm{C} / \mathrm{N}$ values of SOM and POM between wet and dry seasons $(p<0.05)$ were found. In both seasons, SOM had slightly higher values of $\delta^{13} \mathrm{C}$ than POM. In contrast, SOM had lower values of $\delta^{15} \mathrm{~N}$ and $\mathrm{C} / \mathrm{N}$ compared to POM in both seasons.

\section{DISCUSSION}

\section{Trophic relationships among the cultured species}

In the present study, the $\mathrm{C} / \mathrm{N}$ ratio ( $>11)$ of phytoplankton (being a major fraction of POM) indicates that terrestrial material from the rivers is a major source of carbon, since these values are higher than those previously reported for marine phytoplankton (range: 6.7-10) and closer to vascular plants $(>12)$ (Redfield et al. 1963, Holligan et al. 1984, Meyers 1994, Hedges \& Oades 1997, Bale \& Morris 1998, Bates et al. 2005, Lamb et al. 2006). The $\delta^{13} \mathrm{C}$ values of plankton (range: $-25.4 \%$ o to $-25.9 \%$ ) in this study were lower than those reported for Narragansett Bay, USA (mean \pm SD: $-22 \pm 0.6 \%$ ) and Osaka Bay in Japan (range: $-18.0 \%$ o to $-24.0 \%$ ) (Gearing et al. 1984, Mishima et al. 1996). The $\delta^{15} \mathrm{~N}$ values of phytoand zooplankton (range: $7.6-7.8 \%$ ) were within the range reported for marine phytoplankton $(3.0-10 \%)$ (Wada et al. 1991). For oysters, we determined relatively lower values of $\delta^{13} \mathrm{C}$ (mean \pm SD: $-20.03 \pm$ $0.18 \%$ ) and higher values of $\delta^{15} \mathrm{~N}(8.27 \pm 0.13 \%)$ compared to values reported from oysters around a fish cage area in Ailian Bay, China (mean \pm SD: $-20.03 \pm 0.18 \%$; Jiang et al. 2012), indicating that river runoff has been a source of carbon and nitrogen in oysters of the present study. The $\delta^{13} \mathrm{C}$ and $\delta^{15} \mathrm{~N}$ values $(-19.0 \%$ and $11.1 \%)$ we determined in cultured fish were lower than the average values $(-17 \%$ and $13 \%$, respectively) observed for marine fishes (Mays 2000).

The wet season in SGB is characterized by peak IMTA activities, when fish cage culture occurs in conjunction with shellfish and seaweed. In addition, maximum freshwater inputs influence the sources and flow of OM (carbon and nitrogen) among cultured species and other organisms at various trophic levels. In the wet season, along with integrated aquaculture, primary production is a large carbon source for higher trophic levels. In the summer months, SGB usally experiences comparatively high light intensity and water temperature, which promote phytoplankton growth. This is reflected by the high chl a concentrations we observed in this season and the positive correlation between chl $a$ and the $\delta^{13} \mathrm{C}$ of POM that is dominated by phytoplankton (Fig. 6). Similar findings were reported by Lehmann et al. (2004), who showed that an increase in $\delta^{13} \mathrm{C}$ values of POC is associated with increasing primary productivity due to the seasonal environmental conditions, including water temperature and light intensity. The enhanced primary production is connected to the high input of nutrients by freshwater inflow, as indicated by depleted $\delta^{13} \mathrm{C}$ values of POM in the present study. It is possible that zooplankton in this bay feed on terrestrial detritus, which has $\delta^{13} \mathrm{C}$ and $\delta^{15} \mathrm{~N}$ values similar to POM. Shellfish are usually considered to derive a large proportion of organic carbon from phytoplankton (Xu \& Yang 2007). By identifying the relative con-

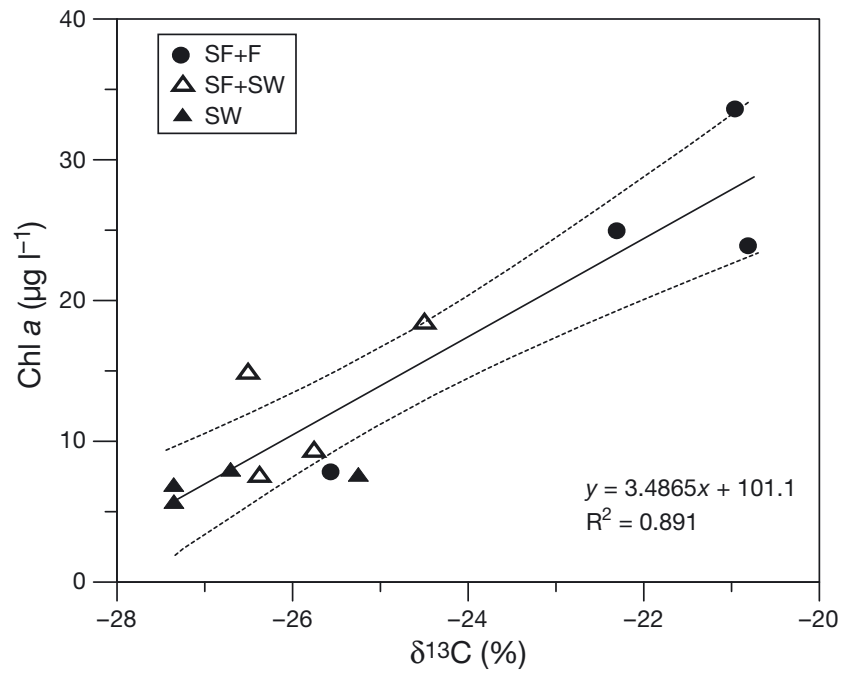

Fig. 6. Relationship between $\delta^{13} \mathrm{C}(\%)$ of particulate organic matter and chlorophyll a concentration in 3 different aquaculture areas (see Fig. 1) of Sanggou Bay during the wet season 
tribution of aquaculture-derived OM and its impact on water quality, the present study shows that shellfish can be considered to function as biological filters in coastal integrated aquaculture, as was reported previously for land-based integrated aquaculture (Shpigel et al. 1991, Shpigel \& Neori 1996). In the coastal area different kinds of POM are present that may serve as a food source for shellfish (oyster and scallop) (Dame 1996). The observed increase in $\delta^{15} \mathrm{~N}$ from phytoplankton and POM to omnivorous fish was indicative of the trophic position of the cultured species in SGB: $\delta^{15} \mathrm{~N}$ ranged from $6.7 \%$ or autotrophs to up to $11.2 \%$ for heterotrophs, reflecting the enrichment in $\delta^{15} \mathrm{~N}$ with increasing trophic level. The $\delta^{15} \mathrm{~N}$ signatures of primary producers (phytoplankton and seaweed) clearly separated the filter feeders (shellfish) from omnivorous fish (Japanese flounder) (Fig. 4). Some species shared the same trophic level, such as cultured fish and oyster (2.16), but differed in $\delta^{13} \mathrm{C}$ values (fish: $-19.0 \pm 0.2 \%$, oyster: $-21.1 \pm 0.2 \%$; mean \pm $\mathrm{SD})$, indicating that these species are up-taking carbon from different sources. In spite of this, cultured fish showed $2 \%$ enrichment in $\delta^{13} \mathrm{C}$ from its primary input source of feeding, i.e. trash fish, while oysters also showed a $\delta^{13} \mathrm{C}$ signature similar to trash fish with $0 \%$ enrichment. In contrast, some species, such as scallop and oyster, showed similar $\delta^{13} \mathrm{C}$ values $(-21.0$ $\pm 0.1 \%$ and $-21.1 \pm 0.2 \%$ [mean $\pm \mathrm{SD}$ ], respectively) indicating the same carbon source, but the difference in their $\delta^{15} \mathrm{~N}$ values revealed that they belong to different trophic levels (1.52 and 2.16, respectively). Similar findings of the same trophic relationship (i.e. different carbon sources with same trophic level and similar carbon sources with different trophic levels) were reported in Jinghai Bay, China (Feng et al. 2014).

In the present study, scallop showed low $\delta^{15} \mathrm{~N}$ isotopic fractionation compared to the average fractionation factor reported elsewhere (3.4; Minagawa \& Wada 1984). Several studies have reported low nitrogen fractionation values for shellfish (Raikow \& Hamilton 2001, Post 2002, Marin-Leal et al. 2008), suggesting that low $\delta^{15} \mathrm{~N}$ enrichment may be due to the specific physiological characteristics of scallops. Moreover, the $\delta^{13} \mathrm{C}$ values of trash fish, seaweed and shellfish were close to each other. We did not collect faeces samples but used an average $\left(\delta^{13} \mathrm{C}=-21.8 \%\right.$ ) of respective values from the literature (Table 2). This average value was close to the $\delta^{13} \mathrm{C}$ value of shellfish, suggesting that shellfish in SGB may also use carbon sources from faecal material released from fish cages, uneaten particles of trash fish and rotten seaweed. Therefore, shellfish cultured in SGB possibly not only help in reducing $\mathrm{OM}$ but may also be able to increase the economic benefit and production and survival rate of other species in the IMTA system by maintaining water quality. Based upon stable isotope analysis, a conceptual model of OM flow among the integrated aquaculture species in SGB was established (Fig. 7). The trophic level efficiency was calculated by dividing the $\delta^{13} \mathrm{C}$ and $\delta^{15} \mathrm{~N}$ values of one trophic level to the next. POM integrated both phytoplankton and zooplankton and acted as a large source of $\mathrm{OM}$ that could be transferred to all the upper trophic levels in the integrated food web structure of SGB. Stable isotope results indicate that scallop and oyster are taking up $>80 \%$ of the OM from these sources in SGB. Bivalves accumulated approx. $90 \%$ of their carbon and $60 \%$ of the nitrogen from fish faeces and uneaten particles of trash fish, but during the wet season only; as opposed to the dry season, when shellfish mostly relied on POM, phytoplankton and zooplankton. Feeding on faeces and trash fish remains during the warm wet season probably helped to meet the high metabolic demand of the shellfish in warmer water temperatures. Alternative sources of OM in the dry season at low temperature may be provided through large-scale cultivation of kelp. Kelp culture produces a considerable amount of rotten kelp particles that can serve as a source of OM to shellfish, whereas shellfish would only be provided a minute amount (1\%) of OM from Gracilaria culture. Omnivorous cultured fish obtained most of their carbon (90\%) and nitrogen (60\%) from trash fish, while other sources were OM from producers and herbivores. In the food web structure of the cultured species of the present study, shellfish played a crucial role in OM accumulation from various sources. In summary, the water quality of SGB is not impacted by OM generated by caged fish and shellfish culture activities; on the contrary, shellfish 


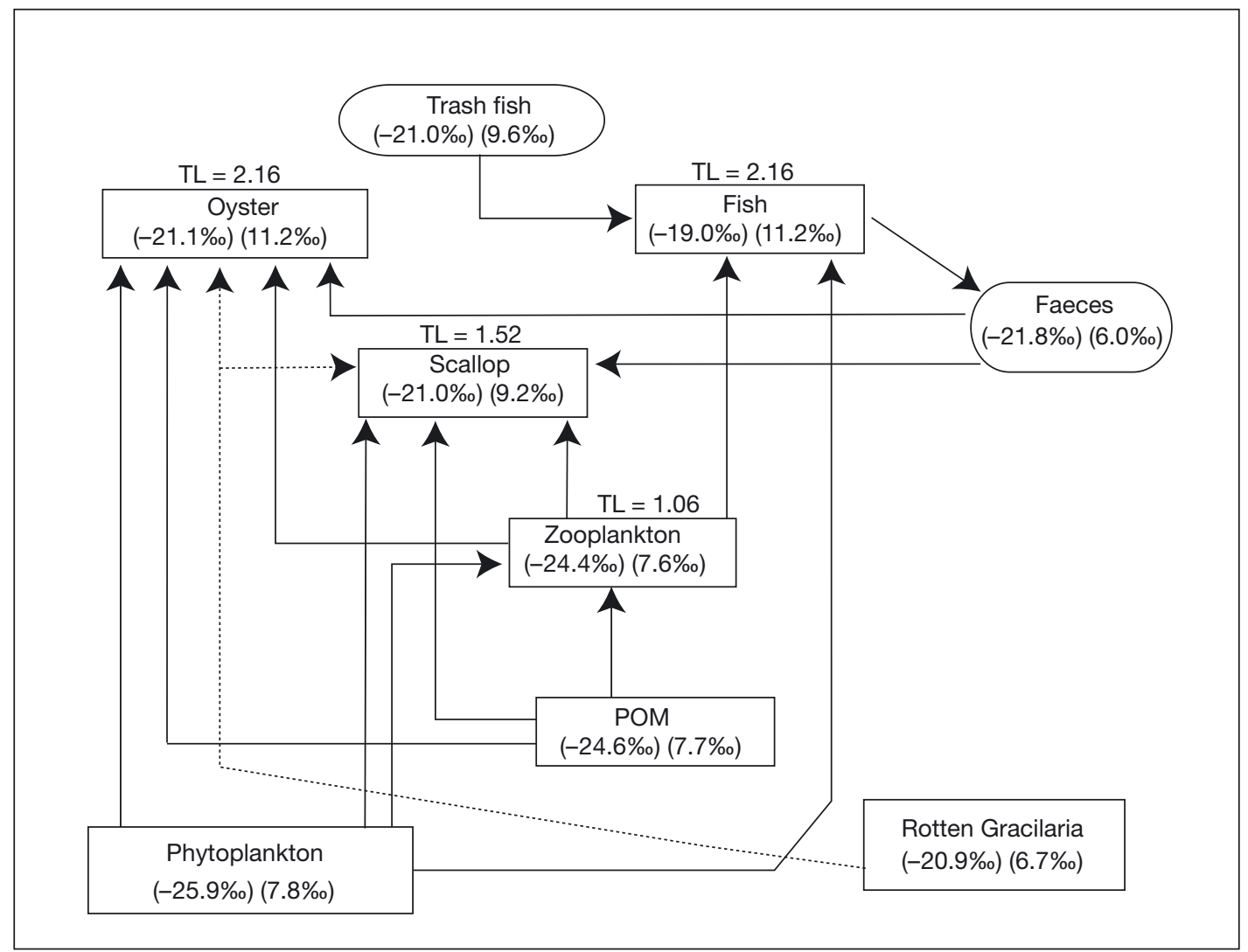

Fig. 7. Conceptual model of carbon flow among the aquaculture species in Sanggou Bay on the basis of stable isotope analysis. Values in parentheses are $\delta^{13} \mathrm{C}$ (first) and $\delta^{15} \mathrm{~N}$ (second) isotopic signatures (\%) of various species and represent the flow (arrows; dotted arrows originate from rotten Gracilaria) from one trophic level (TL) to the next, showing the trophic efficiency. The TL is given for each cultured species

co-culture combined with proximity to the YS to allow for water mixing may be helpful in maintaining the water quality of the bay.

\section{Sources of suspended and sedimentary $O M$ across the bay}

In the wet season, higher $\mathrm{C} / \mathrm{N}$ values $(>10)$ of $\mathrm{POM}$ in the $\mathrm{SF}+\mathrm{F}$ (near coast) and $\mathrm{SF}+\mathrm{SW}$ (central bay) culture areas indicate the influence of terrestrial OM. The lower C/N ratio in the Gracilaria monoculture area (near YS) may indicate the high consumption of nitrogen in this area or mixing with YS water. In the wet season, POM in the $\mathrm{SF}+\mathrm{F}$ culture area showed higher values of $\delta^{13} \mathrm{C}$ with a decreasing trend towards offshore, indicating OM load in the $\mathrm{SF}+\mathrm{F}$ nearcoast area compared to the other 2 areas. The lower values of $\delta^{13} \mathrm{C}$ towards offshore may have resulted from the presence of degraded OM (Khodse et al. 2007). Another reason could be that high freshwater discharge during the wet season may have resulted in the rapid distribution of OM to offshore waters, preventing utilization and deposition of $\mathrm{OM}$ in the bay. By contrast, the higher values of $\delta^{15} \mathrm{~N}$ of POM in the $\mathrm{SF}+\mathrm{F}$ culture area (near-shore area) compared to the central SF+SW and outer SW culture areas may be attributed to nitrate derived from human activities coupled with increased denitrification (Michener \& Schell 1994, McClelland et al. 1997, Chanton and Lewis 1999, Miller et al. 2010). The decreasing trend of $\delta^{15} \mathrm{~N}$ in POM towards the sea suggests an offshore source of nitrogen (Miller et al. 2011). In the wet season, higher values of $\delta^{13} \mathrm{C}(-22.4 \%$ to $-21.4 \%$ o $)$ in SOM of 3 culture areas displayed the isotopic signature of marine-derived OM (Wada et al. 1987, Tan et al. 1991, Mishima et al. 1996, Barros et al. 2010). Similar results for SOM $\delta^{13} \mathrm{C}$ were found by Meksumpun et al. (2005) (avg. $\delta^{13} \mathrm{C}=-21.0 \%$ ) in the Gulf of Thailand, as well as in an earlier study by Gearing et al. (1984), who reported $\delta^{13} \mathrm{C}$ values indicative of a plankton source in SOM, ranging from $-22.2 \pm 0.6 \%$ to $-20.3 \pm 0.6 \%$ in Narragansett Bay, USA and an average value of $-21.0 \%$ in Malaysian waters. Rela- 
tively low values of $\delta^{15} \mathrm{~N}$ in SOM of all culture areas in the present study indicate a marine source of the deposited OM. This is supported by an increasing trend of $\delta^{15} \mathrm{~N}$ in SOM of the 3 aquaculture areas from shellfish to polyculture to seaweed, suggesting the import of OM from the sea.

In the present study, $\delta^{13} \mathrm{C}, \delta^{15} \mathrm{~N}$ and $\mathrm{C} / \mathrm{N}$ of POM are applied to describe OM sources The $\delta^{13} \mathrm{C}$ of POM in the wet season has either lower or higher values than SOM in the 3 culture areas. Therefore, in the wet season, due to maximum freshwater discharge into the bay, as indicated by a decreasing inshore salinity trend, fluctuations in $\delta^{13} \mathrm{C}$ and $\delta^{15} \mathrm{~N}$ values of POM among the stations imply different sources of OM. The results of the present study suggest that during the wet season, OM in SGB originates from 2 sources; marine and terrestrial. Hence to quantify the relative contribution of each source, a 2 end-member mixing model has been applied to the wet season data, using terrestrial and marine end-members values based on the model by Calder \& Parker (1968).

The equation used in this model is given as:

TC $(\%)=\delta^{13} \mathrm{C}_{\text {mar }}-\delta^{13} \mathrm{C}_{\mathrm{sam}} / \delta^{13} \mathrm{C}_{\mathrm{mar}}-\delta^{13} \mathrm{C}_{\text {ters }} \times 100$

where TC is the terrestrial carbon, $\delta^{13} \mathrm{C}_{\mathrm{mar}}$ is the marine end-member, $\delta^{13} C_{\text {ters }}$ is the terrestrial endmember, and $\delta^{13} \mathrm{C}_{\mathrm{sam}}$ is the measured value of the samples at each station. Generally, terrestrial OM has relatively low values of $\delta^{13} \mathrm{C}$ and $\delta^{15} \mathrm{~N}$. Therefore, in our study, $\delta^{13} \mathrm{C}(-27.4 \%)$ and $\delta^{15} \mathrm{~N}(4.7 \%)$ values of $\mathrm{POM}$ were selected as terrestrial end-members, which are closer to terrestrial end-member values of $\delta^{13} \mathrm{C}$ and $\delta^{15} \mathrm{~N}$ identified in a number of previous studies (Peters et al. 1978, Wada et al. 1987, Middleburg \& Nieuwenhuize 1998, Barros et al. 2010). In the present study, mean $\delta^{13} \mathrm{C}(-19.0 \%)$ and $\delta^{15} \mathrm{~N}(9.4 \%)$ values of cultured fish and oyster, respectively, have been selected as marine end-members and are close to the values of Middleburg \& Nieuwenhuize (1998). Model results indicated that during the wet season in
SGB, an average of $\sim 72 \%$ of $\mathrm{OM}$ in POM is derived from the land.

In contrast to the wet season, during the dry season the range and average values of $\delta^{13} \mathrm{C}$ and $\delta^{15} \mathrm{~N}$ of $\mathrm{POM}$ in all culture areas were within the range of marine-derived $\mathrm{OM}$ reported in previous studies (Gearing et al. 1984, Wada \& Hattori 1991, Meyers 1997, Lamb et al. 2006). The high $\mathrm{C} / \mathrm{N}$ values observed among $\mathrm{SF}+\mathrm{F}$ culture stations might have resulted from the presence of degraded OM (Khodse et al. 2007) due to limited river inflow during the dry season, while in the other 2 culture areas, $\mathrm{C} / \mathrm{N}$ values were in the range of marine-derived OM (Meyers 1994). SOM of all culture areas was assumed to be derived from suspended matter during the dry season, as indicated by their mean values of $\delta^{13} \mathrm{C}$ $(\mathrm{SOM}=-22.4 \pm 0.3 \%$ and $\mathrm{POM}=-23.2 \pm 0.6 \%$; ANOVA, $\mathrm{p}<0.05)$, revealing material exchange between the 2 different OM pools (Meksumpun et al. 2005).

Comparing both seasons, significant differences were found between $\delta^{13} \mathrm{C}$ and $\delta^{15} \mathrm{~N}$ values of SOM and POM (ANOVA, p < 0.05). The relatively high values of $\delta^{13} \mathrm{C}$ in SOM showed that SOM in SGB was derived from the same marine source in both seasons. The reason for this could be that sediments were receiving $\mathrm{OM}$ from autochthonous sources originating from diatoms, bacteria, and green macroalgae (Gao et al. 2012). The significant difference between SOM and POM in the wet season shows less exchange between the $2 \mathrm{OM}$ pools, the reason being either high freshwater inflow or assimilation of terrestrial-derived OM in the upper water column. In both seasons, the $\delta^{15} \mathrm{~N}$ values were also close to those reported for marine-derived OM in previous studies (Gearing et al. 1984, Wada et al. 1991). The comparison of our carbon and nitrogen isotopic signatures of the POM in SGB with that of other bays (Table 3) suggests that the water quality of SGB is not significantly impacted by land-based sources of OM. The

Table 3. Ranges of carbon and nitrogen isotope values of the present study compared to previous values reported in the literature from different coastal areas having aquaculture activities or being impacted by various sources of organic matter. nd: not determined

\begin{tabular}{|llccl|}
\hline Study area & Activity / source of impact & $\delta^{13} \mathrm{C}(\%)$ & \multirow{2}{*}{$\delta^{15} \mathrm{~N}(\%)$} & References \\
\hline Southwestern Thailand & Land-based aquaculture & -27.3 to -20.6 & $3.1-8.4$ & Kuramoto \& Minagawa (2001) \\
Gaeta Gulf (Mediterranean) & Bivalve and cage culture & -25.0 to -19.8 & nd & Mazzola \& Sarà (2001) \\
Kat O Bay, Hong Kong & Land-based aquaculture & -21.2 to -20.1 & $8.5-10.2$ & Wai et al. (2011) \\
Simon Bay, South Africa & Anthropogenic & -24.8 to -19.3 & nd & Filgueira \& Castro (2011) \\
Kosirina Bay, Croatia & Anthropogenic & nd & $4.3-8.3$ & Dolenec et al. (2011) \\
Sanggou Bay & Bivalve and cage culture & -27.4 to -19.0 & $4.7-9.4$ & Present study \\
\hline
\end{tabular}


high production of phytoplankton and the $\delta^{13} \mathrm{C}$ values in all cultured species indicate that the bay acts as source of carbon, and that this carbon is utilized by cultured species and removed from the bay at their harvest. However, the high $\mathrm{C} / \mathrm{N}$ values indicate that SGB may act as a sink for anthropogenic material (river input).

\section{CONCLUSIONS}

In SGB, phytoplankton production is one of the main sources of OM to higher trophic levels during the wet season, as indicated by a positive correlation between $\delta^{13} \mathrm{C}$ and POM, the latter of which containing a large proportion of phytoplankton. Trophic relationships showed that cultured fish and oyster take up carbon from different sources while sharing the same trophic level (2.16). On the other hand, oyster and scallop used the same carbon sources in spite of different trophic levels (2.16 and 1.52 respectively). Based on the results of the stable isotope analysis, our conceptual model for the wet season suggested that $\sim 80 \%$ of the OM including faecal material and riverine $\mathrm{OM}$ in the form of POM is extracted by oyster and scallop. In the dry season, these species still mainly rely on POM but to some extent also use rotten kelp. C/N values $>11$ for POM indicate the partly terrestrial origin of OM in $\mathrm{SGB}$; however, in the wet season the bay also functions as a source of carbon due to the high phytoplankton production and aquaculture activities, while high $\mathrm{C} / \mathrm{N}$ values indicate that SBG may also be a sink of anthropogenic material (river input). Therefore, both culture areas $\mathrm{SF}+\mathrm{F}$ (avg. $\mathrm{C} / \mathrm{N}=12.69$ ) and $\mathrm{SF}+\mathrm{SW}$ (avg. $\mathrm{C} / \mathrm{N}=13.11$ ) in SGB are highly impacted by OM from river inflow and human activities in the wet season, as indicated by average $\mathrm{C} / \mathrm{N}$ ratios in POM. In the dry season, POM in the near-shore $\mathrm{SF}+\mathrm{F}$ culture area showed high $\mathrm{C} / \mathrm{N}$ values of $11.97 \pm 2.08$ (mean $\pm \mathrm{SD}$ ) relative to the other 2 areas with $\mathrm{C} / \mathrm{N}$ values $(<10)$ indicative of more marine-derived OM. The outer SW culture area (near YS) is highly impacted by YS water. However, C/N values $(<10$, typical of a marine source) indicate the influence of YS, but the $\delta^{13} \mathrm{C}$ values show the signature of terrestrial OM that may result from river input and degraded OM. Results from the 2 end-member mixing model revealed that for POM an average of $72 \%$ $\mathrm{OM}$ is derived from land during the wet season. $\delta^{13} \mathrm{C}$ and $\delta^{15} \mathrm{~N}$ signatures show that OM in SOM during both the wet and dry seasons is mostly of marine origin. However, a detailed study on terrestrial organic input from rivers into the SGB is required to better understand the sources of OM and its influence on the water quality of the bay. In addition, studies investigating the role of benthic, non-aquaculture organisms and seagrass could further the understanding of the detailed food web structure of the bay.

Acknowledgements. This study was supported by the Ministry of Science and Technology of China (MoST-China) through 'Sustainability of Marine Ecosystem Production under Multi-stressors and Adaptive Management (MEcoPAM)' Project 973-3 (No. 2011CB409801) in the period of 2011-2015. The authors are very grateful to colleagues from the Ocean University of China and East China Normal University for their help with the fieldwork and laboratory experiment. T.M. thanks the China Scholarship Council (CSC) for providing a PhD scholarship and the National Institute of Oceanography Pakistan for granting study leave and moral support.

\section{LITERATURE CITED}

Alabaster JS (1982) Report of the EIFAC workshop on fishfarm effluents. Silkeborg, Denmark, 26-28 May 1981. EIFAC Tech Rep 41

Bale A, Morris A (1998) Organic carbon in suspended particulate material in the North Sea: effect of mixing resuspended and background particles. Cont Shelf Res 18: 1333-1345

Barros GV, Martinelli LA, Novais TMO, Ometto JPHB, Zuppi GM (2010) Stable isotopes of bulk organic matter to trace carbon and nitrogen dynamics in an estuarine ecosystem in Babitonga Bay (Santa Catarina, Brazil). Sci Total Environ 408:2226-2232

Bates NR, Dennis A, Hansell DA, Moran SB, Codispoti LA (2005) Seasonal and spatial distribution of particulate organic matter (POM) in the Chukchi and Beaufort Seas. Deep-Sea Res II 52:3324-3343

Buschmann AH, Varela DA, Hernández-González MC, Huovinen P (2008) Opportunities and challenges for the development of an integrated seaweed-based aquaculture activity in Chile: determining the physiological capabilities of Macrocystis and Gracilaria as biofilters. J Appl Phycol 20:571-577

Calder JA, Parker PL (1968) Stable carbon isotope ratios as indices of petrochemical pollution of aquatic systems. Environ Sci Technol 2:535-539

Chanton JP, Lewis FG (1999) Plankton and dissolved inorganic carbon isotopic composition in a river-dominated estuary: Apalachicola Bay, Florida. Estuaries 22:575-583

Costanzo SD, O'Donohue MJ, Dennison WC, Loneragan NR, Thomas M (2001) A new approach for detecting and mapping sewage impacts. Mar Pollut Bull 42:149-156

Cui Y, Wu Y, Zhang J, Wang N (2012) Potential dietary influence on the stable isotopes and fatty acid compositions of jellyfishes in the Yellow Sea. J Mar Biol Assoc UK 92: 1325-1333

Dame R (1996) Ecology of marine shellfish: an ecosystem approach. CRC Press, Boca Raton, FL

Dolenec M, Žvab P, Mihelčić G, Lambaša Belak Ž and others (2011) Use of stable nitrogen isotope signatures of anthropogenic organic matter in the coastal environ- 
ment: a case study of the Kosirina Bay (Murter Island, Croatia). Geol Croatica 64:143-152

Duarte C (1995) Submerged aquatic vegetation in relation to different nutrient regimes. Ophelia 41:87-112

$>$ Evgenidou A, Valiela I (2002) Response of growth and density of a population of Geukensia demissa to landderived nitrogen loading, in Waquoit Bay, Massachusetts. Estuar Coast Shelf Sci 55:125-138

Fang JG, Funderud J, Qi ZH, Zhang JH, Jiang ZJ, Wang W (2009) Sea cucumbers enhance IMTA system with abalone, kelp in China. Global Aquacult Advocate July/August 2009:49-51

Fang JG, Kuang SH, Sun HL, Sun Y (1996a) Study on the carrying capacity of Sanggou Bay for the culture of scallop Chlamys farreri. Mar Fish Res 17:18-31 (in Chinese with English Abstract)

Fang JG, Sun HL, Kuang SH, Sun Y (1996b) Assessing the carrying capacity of Sanggou Bay for culture of kelp Laminaria japonica. Mar Fish Res 17:7-17 (in Chinese with English Abstract)

Feng JX, Gao QF, Dong SL, Sun ZL, Zhang K (2014) Trophic relationships in a polyculture pond based on carbon and nitrogen stable isotope analyses: a case study in Jinghai Bay, China. Aquaculture 428-429:258-264

Ferreira G, Andersson HC, Corner RA, Desmit X and others (eds) (2007) SPEAR: sustainable options for people, catchment and aquatic resources. EU 6th framework programme FP6-2002-INCO-DEV-1, IMAR - Institute of Marine Research, Coimbra

Filgueira R, Castro BG (2011) Study of the trophic web of San Simón Bay (Ría de Vigo) by using stable isotopes. Cont Shelf Res 31:476-487

$>$ Gao X, Yang Y, Wang C (2012) Geochemistry of organic carbon and nitrogen in surface sediments of coastal Bohai Bay inferred from their ratios and stable isotopic signatures. Mar Pollut Bull 64:1148-1155

Gearing GN, Gearing PL, Rudnick DT, Requejo AG, Hutchins MJ (1984) Isotope variability of organic carbon in a phytoplankton based temperate estuary. Geochim Cosmochim Acta 48:1089-1098

Gowen RJ, Weston DP, Ervik A (1991) Aquaculture and the benthic environment: a review. In: Cowey CB, Cho CY (eds) Nutritional strategies and aquaculture waste. Fish Nutrition Research Laboratory, University of Guelph, Guelph, p 187-205

Hall POJ, Holby O, Kollberg S, Samuelsson MO (1992) Chemical fluxes and mass balances in a marine fish cage farm. IV. Nitrogen. Mar Ecol Prog Ser 89:81-91

Hayes JM (2004) An introduction to isotopic calculations. Woods Hole Oceanographic Institution, Woods Hole, MA, p 1-10

> Hedges JI, Oades JM (1997) Comparative organic geochemistries of soils and marine sediments. Org Geochem 27:319-361

> Holby O, Hall POJ (1991) Chemical fluxes and mass balances in a marine fish cage farm. II. Phosphorus. Mar Ecol Prog Ser 70:263-272

> Holligan PM, Harris RP, Newell RC, Harbour DS and others (1984) Vertical distribution and partitioning of organic carbon in mixed, frontal and stratified waters of the English Channel. Mar Ecol Prog Ser 14:111-127

Hu J, Peng P, Jia G, Mai B, Zhang G (2006) Distribution and sources of organic carbon, nitrogen and their isotopes in sediments of the subtropical Pearl River estuary and adjacent shelf, Southern China. Mar Chem 98:274-285
Jiang ZJ, Wang GH, Fang JG, Mao YZ (2012) Growth and food sources of Pacific oyster Crassostrea gigas integrated culture with sea bass Lateolabrax japonicus in Ailian Bay, China. Aquacult Int 21:45-52

Karakassis I, Tsapakis M, Hatziyanni E, Papadopoulou KN, Plaiti W (2000) Impact of cage farming of fish on the seabed in three Mediterranean coastal areas. ICES J Mar Sci 57:1462-1471

Khodse VB, Fernandes L, Gopalkrishna VV, Bhosle NB, Fernandes V, Matondkar SGP, Bhushan R (2007) Distribution and seasonal variation of concentrations of particulate carbohydrates and uronic acids in the northern Indian Ocean. Mar Chem 103:327-346

Kuramoto T, Minagawa M (2001) Stable carbon and nitrogen isotopic characterization of organic matter in a mangrove ecosystem on the southwestern coast of Thailand. J Oceanogr 57:421-431

Lamb AL, Wilson GP, Leng MJ (2006) A review of coastal palaeoclimate and relative sea-level reconstructions using $\delta^{13} \mathrm{C}$ and $\mathrm{C} / \mathrm{N}$ ratios in organic material. Earth Sci 75 : $29-57$

> Lehmann M, Bernasconi SM, Mckenzie JA, Barbieri A, Simona M, Veronesi M (2004) Seasonal variation of the $\delta^{13} \mathrm{C}$ and $\delta^{15} \mathrm{~N}$ of particulate and dissolved carbon and nitrogen in Lake Lugano: constraints on biogeochemical cycling in a eutrophic lake. Limnol Oceanogr 49:415-429

Marin Leal JC, Dubois S, Orvain F, Galois R, Blin JL and others (2008) Stable isotopes $\left(\delta^{13} \mathrm{C}, \delta^{15} \mathrm{~N}\right)$ and modeling as tools to estimate the trophic ecology of cultivated oysters in two contrasting environments. Mar Biol 153:673-688

Mays S (2000) New directions in the analysis of stable isotopes in excavated bones and teeth. In: Cox M, Mays S (eds) Human osteology in archaeology and forensic science. Greenwich Medical Media, London, p 425-438

> Mazzola A, Sarà G (2001) The effect of fish farming organic waste on food availability for bivalve molluscs (Gaeta Gulf, Central Tyrrhenian, MED): stable carbon isotopic analysis. Aquaculture 192:361-379

McClelland JW, Valiela I, Michener RH (1997) Nitrogen stable isotope signatures in estuarine food webs: a record of increasing urbanization in coastal watersheds. Limnol Oceanogr 42:930-937

> Meksumpun S, Meksumpun C, Hoshika A, Mishima Y, Tanimoto T (2005) Stable carbon and nitrogen isotope ratios of sediment in the gulf of Thailand: evidence for understanding of marine environment. Cont Shelf Res 25: 1905-1915

> Meyers PA (1994) Preservation of elemental and isotopic source identification of sedimentary organic matter. Chem Geol 114:289-302

> Meyers PA (1997) Organic geochemical proxies of paleoceanographic, paleolimnologic, and paleoclimatic processes. Org Geochem 27:213-250

Michener RH, Schell DM (1994) Stable isotope ratios as tracers in marine aquatic food webs. In: Lajtha K, Michener RH (eds) Stable isotopes in ecology. Blackwell Scientific Publications, Oxford, p 138-157

Middelburg JJ, Nieuwenhuize J (1998) Carbon and nitrogen stable isotopes in suspended matter and sediments from the Schelde Estuary. Mar Chem 60:217-225

> Miller TW, Omori K, Hamaoka H, Shibata JY, Hidejiro O (2010) Tracing anthropogenic inputs to production in the Seto Inland Sea, Japan - a stable isotope approach. Mar Pollut Bull 60:1803-1809

Miller TW, Jaquinto G, McGlone M, Isobe A, Shibata JY, 
Hamaoka H, Omori K (2011) Tracing dynamics of organic material flow in coastal marine ecosystems: results from Manila Bay (Philippines) and Kyucho Intrusion (Japan). In: Omori K, Guo X, Yoshie N, Fujii N, Handoh IC, Isobe A, Tanabe S (eds) Interdisciplinary studies on environmental chemistry: marine environmental modeling and analysis. Terrapub, Tokyo, p 95-104

Minagawa M, Wada E (1984) Stepwise enrichment of ${ }^{15} \mathrm{~N}$ along food chains: further evidence and the relation between $\delta^{15} \mathrm{~N}$ and animal age. Geochim Cosmochim Acta 48:1135-1140

Mishima Y, Hoshika A, Tanimoto T (1996) Movement of terrestrial organic matter in the Osaka Bay, Japan. In: Proc 3rd Int Symp ETERNET-APR: conservation of the hydrospheric environment, Bangkok, Thailand, 3-4 December 1996. Environmental Research Institute, Chulalongkorn University, Bangkok, p 20-25

Peters KE, Sweeney RE, Kaplan IR (1978) Correlation of carbon and nitrogen stable isotopes in sedimentary organic matter. Limnol Oceanogr 23:598-604

Pillay TVR (1991) Aquaculture and the environment. Blackwell Scientific, London

- Post DM (2002) Using stable isotopes to estimate trophic position: models, methods, and assumptions. Ecology 83: 703-718

Raikow DF, Hamilton SK (2001) Bivalve diets in a midwestern U.S. stream: a stable isotope enrichment study. Limnol Oceanogr 46:514-522

Redfield AC, Ketchum BH, Richards FA (1963) The influence of organisms on the composition of seawater. In: Hill MN (ed) The sea, Vol 2. Wiley Interscience, New York, NY, p 26-77

Risk MJ, Erdmann MV (2000) Isotopic composition of nitrogen in stomatopod (Crustacea) tissues as an indicator of human sewage impacts on Indonesian coral reefs. Mar Pollut Bull 40:50-58

Shpigel M, Neori A (1996) The integrated culture of seaweed, abalone, fish and clams in modular intensive land-based systems: I. Proportions of size and projected revenues. Aquacult Eng 15:313-326

Shpigel M, Neori A, Gordin H (1991) Oyster and clam production in the outflow water of marine fish pond in Israel. EAS Spec Publ 14:295

Tan FC, Cai DL, Edmond JM (1991) Carbon isotope geochemistry of the Changjiang Estuary. Estuar Coast Shelf Sci 32:395-403

Vizzini S, Mazzola A (2004) Stable isotope evidence for the environmental impact of a land-based fish farm in the

Editorial responsibility: Simone Mirto (Guest Editor), Castellammare del Golfo, Italy western Mediterranean. Mar Pollut Bull 49:61-70

Vollenweider RA (1992) Coastal marine eutrophication: principles and control. In: Vollenweider RA, Marchetti R, Viviani R (eds) Marine coastal eutrophication. Elsevier, Amsterdam, p 1-20

Wada E, Hattori A (1991) Nitrogen in the sea: forms, abundances and rate processes. CRC Press, Boca Raton, FL

Wada E, Minagawa M, Mizutani H, Tsuji T, Imaizumi R, Karasawa K (1987) Biogeochemical studies on the transport of organic matter along the Otsuchi River watershed, Japan. Estuar Coast Shelf Sci 25:321-336

> Wada E, Mizutani H, Minagawa M (1991) The use of stable isotopes for food web analysis. Crit Rev Food Sci Nutr 30: 361-371

> Wai TC, Leung KMY, Wu RSS, Shin PKS, Cheung SG, Li XY, Lee JHW (2011) Stable isotopes as a useful tool for revealing the environmental fate and trophic effect of open-seacage fish farm wastes on marine benthic organisms with different feeding guilds. Mar Poll Bull 63:77-85

> Wan RJ, Wu Y, Huang L, Zhang J, Gao L, Wang N (2010) Fatty acids and stable isotopes of a marine ecosystem: study on the Japanese anchovy (Engraulis japonicus) food web in the Yellow Sea. Deep-Sea Res II 57: 1047-1057

Xu Q, Yang H (2007) Food sources of three shellfish living in two habitats of Jiaozhou Bay (Qingdao, China): indicated by lipid biomarkers and stable isotope analysis. J Shellfish Res 26:561-567

Ye L, Ritz DA, Fenton GE, Lewis ME (1991) Tracing the influence on sediments of organic waste from a salmonid farm using stable isotope analysis. J Exp Mar Biol Ecol 145:161-174

Yokoyama H (2013) Growth and food source of the sea cucumber Apostichopus japonicus cultured below fish cages-potential for integrated multi-trophic aquaculture. Aquaculture 372-375:28-38

Yokoyama H, Abo K, Ikuta K, Kamiyama T, Higano J, Toda S (2006) Country scenarios for ecosystem approaches for aquaculture. 4. Japan. In: McVey JP, Lee CS, O'Bryen PJ (eds) Aquaculture and ecosystems: an integrated coastal and ocean management approach. The World Aquaculture Society, Baton Rouge, LA, p 71-89

Yokoyama H, Ishihi Y, Abo K, Takashi T (2010) Quantification of waste feed and fish feces using stable carbon and nitrogen isotopes. Bull Fish Res Agen 31:71-76

Zhao J, Zhou S, Sun Y, Fang J (1996) Research on Sanggou Bay aquaculture hydro-environment. Mar Fish Res 17: 68-79

Submitted: March 11, 2015; Accepted: October 1, 2015 Proofs received from author(s): February 19, 2016 